\title{
Dental and Oral Health Education for Elementary School Students through Patient Hygiene Performance Index Indicator
}

\author{
Septian Emma Dwi Jatmika, Muchsin Maulana
}

Faculty of Public Health, Universitas Ahmad Dahlan, Indonesia

\begin{tabular}{l}
\hline \hline Article Info \\
\hline Article history: \\
Received Aug 4, 2018 \\
Revised Sep 8, 2018 \\
Accepted Sep 16, 2018 \\
\hline
\end{tabular}

Keyword:

Attitude

Pedagogical formation

Teaching profession

\begin{abstract}
Caries is a problem that often occurs in school-age children. Special Region of Yogyakarta is a province that has a high DMF-T index by 5.9 and exceeds the national DMF-T index. One of the efforts to improve dental and oral health of school-age children is the health education method using simulation methods, as well as simple techniques that may attract children's attention and be understood. The aim of the current study is to knowing the influence of oral and dental hygiene education intervention on dental and oral hygiene level at SD Negeri 3 Sleman students. This research used a kind of quasi experimental research with one group pretest posttest design. The research was done in SD Negeri 3 Sleman, the sample used was the 3rd graders from 57 students in 2017 . The intervention was done by dental and oral hygiene education. Respondents were examined related to their dental and oral hygiene levels. It was measured by the PHP Index (Patient Hygiene Perfomance) before and after the intervention. According to results, The average score of respondents'dental and oral hygine pre test was 0.082 and the average post test score of respondents'dental and oral hygiene was 1.483. There is the difference of 1.4007. This shows an increament in oral hygiene of the respondent before and after the education. The results of statistical analysis show that there is an influence of oral and dental hygiene which pvalue 0.000 . Thus, there is a need for dental and mouth hygiene education to be conducted regularly and delivered with an interesting method.
\end{abstract}

Copyright $(0) 2018$ Institute of Advanced Engineering and Science. All rights reserved.

\section{Corresponding Author:}

Septian Emma Dwi Jatmika,

Faculty of Public Health, Universitas Ahmad Dahlan, Jl. Prof. Dr. Soepomo S.H, Warungboto, Umbulharjo, Yogyakarta, Indonesia 55164.

Email: septianemma@ikm.uad.ac.id

\section{INTRODUCTION}

Dental caries is a major dental and oral problem in developing countries. Caries is one of the most common problems in school-aged children. Indonesia Ministry of Health reported the national prevalence of dental and oral health problems was around $25.9 \%$ [1]. The percentage of dental and oral problem among children of 5-9 years old group is around $28.9 \%$ and children of 10-14 years old group has a percentage of $25.2 \%$, while in 12 years old group the percentage of children with oral and dental health problems is $24.8 \%$. Based on World Health Organization (WHO) survey in 2007, 77\% of children in Indonesia suffer from dental caries. Yogyakarta Special Region is a province that has a high DMF-T index of 5.9 and exceeds the national DMF-T index.

The most effective preventive action taken to maintain oral health is to brush teeth regularly and correctly [2]. Results show that $93.8 \%$ of Indonesians have brushed their teeth every day, but only $2.3 \%$ brush their teeth properly. Survey of Habit and Attitude in 2012 in Indonesia showed that the behavior of toothbrushing at night before bed was recorded low. In the 5-10 years old group, only 13\% of children have a 
habit of brushing their teeth at night before bed [1]. In the age of 11-15 years old group only $22 \%$ who have a habit of brushing teeth at night before bed, but while sleeping bacteria in the mouth develops twice stronger.

Children around 6 to 12 years old or school-aged children are still less aware of how to maintain oral hygiene [1]. Therefore, efforts to maintain oral health should be done from an early age. Primary school age is an ideal time to train a child's motor skills, including brushing teeth [3]. One of the efforts in improving oral health is health education method. According to Angela tooth brushing skills should be taught and emphasized in children in all ages, especially school children because at that age is easy to accept and instill basic values [4]. School children need to learn how to improve their brushing skills, especially in children with low oral hygiene levels and inadequate brushing skills, are expected to change behaviors that adversely affect health and related to health norms.

Good models and simple techniques need to be given as examples of educational ways of brushing teeth for children. The way to present oral and dental health education in children should be made as attractive as possible through attractive counseling without reducing educational content, simulations or live demonstrations, audio visual programs or controlled toothbrushing [3].

In Yogyakarta Special Region (DIY) recorded 93.6\% of people who behave to brush their teeth every day, but only $3.4 \%$ who brush their teeth properly. Tooth brushing behavior is most commonly done after a morning shower with $88.6 \%$ percentage, whereas time after eating the society often do not brush the teeth, it is around 5.2\% [1]. Health Profile of Sleman District in 2013, there are ten major outpatient diseases in various society health center for all age groups including dental caries disease. Patients with dental caries in Sleman District in 2012 was ranked to be the eightth with the number of patients as many as 14.841 inhabitants.

\section{RESEARCH METHOD}

The research method was quasi experimental with one group pretest posttest design. Research conducted in 2017 at SD Negeri 3 Sleman, 3rd graders. There were 49 students participated in this research. The interventions conducted are oral and dental hygiene education. Respondents are examined related to their dental and oral hygiene levels. One of the factors that influence dental and oral hygiene is the use of brackets. This can be a confounding in research. Therefore, to overcome this, the research sample taken were respondents who met the inclusion criteria, that is students who did not use the bracket. Dental and oral hygiene levels were measured by the PHP Index (Patient Hygiene Perfomance) before and after the intervention. The required instruments are liquids of disclosing solution, toothbrush and toothpaste, and diagnostic set (glass mouth, sonde, tweezers, and excavator). Analysis of the results of the study was conducted using paired $t$ test with $95 \%$ confidence level and $\alpha=0.05$. Ethical clearance for this research was obtained from the research ethics committee of Universitas Ahmad Dahlan, Indonesia (Letter of Ethical Approval, Number 011705054). Appropriate ethical conduct was maintained throughout the study.

\section{RESULTS AND DISCUSSION}

The number of respondents studied was 49 students. All of respondents are around age 9 years $(100 \%)$. The majority of respondents are male (59.2\%). Percentage of good PHP index is greater than moderate PHP index.

The statistical test is used to analyze the average difference of the independent variable with the dependent variable. The bivariate analysis in this study was Paired Sample Test. Paired Sample Test was done by looking at value of Pvalue $<0.05$ aimed to know whether there is difference of mean between before and after giving of education. Then continued to count magnitude difference between before education and after education. Paired Sample Test Results of Effect of Dental and Moral Hygiene Education on Dental and Oral Hygiene Students at SD Negeri 3 Sleman was presented on Table 1.

Table 1 shows that the average value of pre test of dental and mouth hygiene respondents is 0.082 and the average post test of dental and mouth hygiene respondents is 1.4830 . There is a difference which is around 1.4007. This shows an increase in dental hygiene of the respondent before and after being educated. The results of statistical analysis showed that there is influence of oral and dental hygiene education to dental hygiene where pvalue 0.000 .

Table 1. Paired Sample Test Results

\begin{tabular}{ccccc}
\hline Group & Frequency & Average & SD & p Value \\
\hline Pre Test & 49 & 0.0823 & 0.62846 & 0.000 \\
Post Test & 49 & 1.4830 & 0.19744 & \\
\hline
\end{tabular}


Based on the results of research conducted at SD Negeri 3 Sleman, obtained respondents are at the age of 9 . It is $100 \%$. Most of respondents gender are male which is 29 respondents (59.2\%) and 20 respondents $(40.8 \%)$ are female. All respondents are in the age of 9 due to class levels suggested by the school ,as well as considering the existence of inclusion criteria and exclusion from the researcher, they are $3^{\text {rd }}$ grader elementary school who does not use braces.

The result of bivariate analysis about the influence of oral and dental hygiene education on dental and oral hygiene shows that there is difference of mean value before and after education. When pre-test the average value is 0.0823 but after doing the post test the average value becomes 1.4830 . This shows that there is a difference in mean score between before and after education of 1.4007 and indicates an increase in oral hygiene before and after education. Improvement of dental hygiene and mouth of respondents caused by the researcher who gave intervention in the form of giving about tooth and mouth hygiene on respondent using simulation method with jaw model media. The results of counseling is students' knowledge increases so it is expected to fix well the maintainance of dental and oral hygine which can be applied everyday. The value of paired sample test analysis is 0.000 ; it can be concluded as the influence of oral and dental hygiene education on oral and dental hygiene level among elementary school students of SD Negeri 3 Sleman. Thus, students can understand the material presented by the researcher related to oral hygiene, rsuted in to the increased levels of oral and dental hygiene. Characterized by a decrease in the score of PHP students. Knowledge or cognitive is a very important domain for the formation of one's actions [5]. Behavior based on knowledge will be more lasting than behavior that is not based on knowledge. If the recipient of the new behavior is based on knowledge, awareness and a positive attitude then the behavior of the recipients will be long lasting. In the other hand without the knowledge, it won't be long lasting. This is in line with previous research which stated that students who have good knowledge have a chance 2.2 times to have good dental and oral hygiene status [6].

Materials given by researchers to improve students' knowledge about oral hygiene during counseling include good and correct tooth brushing techniques, brushing time, toothbrush form and diseases that is caused by not doing brusing teeth properly. The material is given because the students need to understand well so that the maintenance of good dental and oral health of the childern is good along with their dental and oral hygine level. Several research results stated that there is correlation between tooth brushing frequency and dental hygiene level, there is correlation between oral hygiene with brushing skill in blind children ( $p$ value $=0.002)$, there is difference of meaningful index debris between soft and medium soft brush $(\mathrm{p}$ value $=$ 0.077), there is correlation between bristle damage to the level of dental hygiene in children ( $p$ value $=0.002)$ and there is correlation of dental maintenance behavior with caries experience score $(\mathrm{p}$ value $=0.03)$ and oral hygiene score $(p$ value $=0.00)[7-11]$.

Dental and oral health education is an educational process that aims to improve oral health. One of the theoretical foundations of the use of methods and media in the educational process, the Dale's Cone Experience Theory. According to the theory, there are several methods that can be used in the educational process. Basically the educational process involving more senses will be easier to be accepted and remembered by individuals [5] [12-14]. In this study, researchers conducted counseling with educational methods using lectures and simulations of brushing teeth. The method of simulating the practice of brushing the teeth can make the passive learning atmosphere become more active, the children move to be carefree, so that the child is able to capture more messages or information delivered [15].

Similar research reported there was a higher knowledge increase by a score difference of 30 in the simulated game group given about dental health education with snake ladder games compared to lecture groups [16]. Dental health education using a simulated snake game ladder resulted to the child can see more than one of the five senses. The more the five senses used the better. Even more messages or information will be obtained easily [17]. In essence, humans learn through six levels, and from what people see and hear, it is said they will learn as much as $50 \%$ [18].

Provision of oral and dental education will be more effective and optimal if it uses the right methods and media. Provision of dental education requires aids or props to facilitate the educational goals to receive what is delivered. In this process one can obtain knowledge in the form of information through the existing educational media. Education media is a tool in an educational process. Media has an important role in maximizing the delivery of the message so that it can be well received by the target of education. In this study, researchers used the jaw model as a visual aid in the extension process. The jaw model is used as a visual aid tool to assist the researcher when describing good and correct tooth brushing techniques. Dental brushing technique is taught as vertical, horizontal, rotating, vibration (vibrate), circular and physiological for every part of mouth [19].

When dental and oral health education interventions were conducted using a simulation method using the jaw model, students were shown various forms of teeth and how to brush teeth properly and correctly. The students are directed to feel the jaw model so that it can recognize the various forms of human 
teeth, namely the incisors, canine teeth, small molars and large molars. Students can also distinguish teeth in the maxilla and teeth in the lower jaw. By groping the grooves of the teeth on the model, the students were able to know the gums on the jaw model. Students also recognize the various surfaces of the tooth, the surface of the tooth facing the lips or cheeks (the outer surface of the tooth), the surface of the tooth facing the tongue or the ceiling (the inner surface of the tooth) and the chewing area of the tooth. Then the students are guided to perform motor movement brushing teeth by using a toothbrush without paste on the jaw model. After that the students are simultaneously guided to do toothbrush simulation using good and correct technique. When getting a dental health education using a simulated method by the media of the jaw model, then the students will use their four senses, namely the sense of touch, the listener, the vision and the sense. Similar research reported there was a significant difference in the sample groups which got education about oral hygiene using jaw models before and after intervention [20]. The results showed that there was a decrease of PHP index score in the sample group after intervention.

Some principles in the selection of educational media should also be considered. Since the selected media must be tailored to the material that is goig to be delivered; educators must understand the characteristics of the media so that between the media and the methods used are appropriate; the suitability of the media used by the target group; as well as the completeness of the media shoould be considered as well. In order to provide better perception to the target of education [21]. In this study, researchers used the method of simulation with media jaw jaw model as a visual aid in the extension process in elementary school students. Methods and media are tailored to several things, the first material to be delivered is about good brushing techniques and correct time of brushing teeth, toothbrush form and diseases due to not brushing teeth properly and correctly. Therefore the need for props to help visualization of the child. Second, the simulation method is chosen because when delivering the material there is a need to practice good and correct way of brushing teeth. Therefore it is necessary to do the simulation of good and correct way. Third, the provision of dental and oral hygiene education using the simulation method with the jaw model media is suitable for elementary students, because the simulation method stimulates the child to be active. Thus it can be concluded that the provision of oral and dental hygiene education in elementary school children using simulation methods with media jaw model can be used as a medium of learning while playing for children, so it can motivate children to learn.

This is in line with several studies. On the provision of dental health education in children using several methods and media which states that dental health education using video media $(p$ value $=0.000)$ and media flip chart $(\mathrm{p}$ value $=0.000)$ can improve the knowledge of dental and child health significantly, dental health education using booklet media $(\mathrm{p}$ value $=0.025)$ and media flip chart $(\mathrm{p}$ value $=0.008)$ can increase knowledge of tooth and child meaningfully, cartoon animation media effectively change dental and oral health care behavior to be better $p=0.000)$, health education using audio visual media $(p$ value $=0.000)$ can improve dental and oral health maintenance, dental and mouth health counseling with power point media ( $p$ value $=0.001)$ and flipchart $(p$ value $=0.001)$ increase the level of knowledge of children [22-26] .

One of the way that can be done is to focus the reach of school-based dental services such as School Dental Health Efforts (UKGS) by instilling the importance of healthy behavior since the child who is in elementary school until he completes his education at high school level. The most effective preventive measures are those undertaken by students in the school because healthy lifestyles should be emphasized early and carried out continuously to become habits [27] [28]. In addition, this group is also more easily formed considering students are always in guidance and supervised by the teachers so it is very potential to implant habit of healthy living behavior. In Act No. 23 of 1992 on Health mentioned that the implementation of school health is aimed to improve the ability of healthy life for learners so that they can learn, grow and develop harmoniously and optimally become more qualified human resources. One of the advantages of school-based health programs is that it provides an opportunity to reach more children during the early development period when the health patterns can still be changed or modified. The state of the school also provides a supportive atmosphere for learning and the reinforcement of children so that teachers can use new strategies or methods to encourage children to participate in dental and oral disease prevention measures [27]. Therefore, it needs to be a positive support, especially from the school to continue providing oral hygiene education for students using methods and media whch are interesting periodically, in order to improve the level of children health, especially students'dental and oral health to get better

\section{CONCLUSION}

There is difference of mean value of dental and oral hygiene level of respondent. This shows the improvement of dental and oral hygiene of respondents before and after getting the education. The result of statistical analysis shows that there is influence of oral and dental hygiene education to dental hygiene where 
pvalue 0.000 . Thus, there is a need for dental and mouth hygiene education to be conducted regularly and delivered with an interesting method.

\section{REFERENCES}

[1] Indonesia Ministry of Health. Basic Health Research. Health Research and Development, Jakarta, 2013.

[2] Oktrianda, Bedi. Time Relation, "Brushing Teeth Techniques and What to Consume with Dental Caries Occurrence at Primary School 66 Payakumbuh in Working Area of Payakumbuh Lampasi Public Health Center 2011". Thesis. Universitas Andalas, Padang, 2011.

[3] Riyanti, Eriska. "Education Relation of Tooth Brushing With Oral Hygiene And Mouth Levels Integrated Islamic Primary School (SDIT) Imam Bukhari”. Thesis. Universitas Padjadjaran Bandung, 2005.

[4] Angela, A. "Primary Prevention in High-Risk Caries Children". Dental Juornal. 38 (3), 130. July-September, 2005.

[5] Notoatmodjo, S. Health Promotion Theory and Applications, Rineka Cipta. Jakarta, 16-8, 2010.

[6] Gede, Y. I., Karel, P., Ni Wayan, M. "Knowledge Relation of Tooth and Mouth Hygiene with Dental and Oral Hygiene Status at Senior High School Students of 9 Manado". Jurnal e-Gigi (eG). 1 (2), 84-88, 2013.

[7] Anitasari, S., Nina E. R. "Relation of Frequency Brushing Teeth with Level of Dental Hygiene and Mouth of Elementary School Students in Palaran Subdistrict, Samarinda, East Kalimantan Province”. Dental Magazine (Dental Journal). 38 (2), 88-90, 2005.

[8] Sabilillah, M. F., Ane, K. "Oral Hygiene Relations with Teeth Brushing Skills in Blind Children". Journal ARSA (Actual Research Science Academic). 2 (2), 23-28, 2017.

[9] Ambarwati, T., Aan, F, Samjaji. "Differences Brushing Teeth Using Bristle Medium and Soft Brush on Debris Index on Students Department of Keperawatn Teeth". Journal ARSA (Actual Research Science Academic). 2 (2), $29-34,2017$.

[10] Nugroho, C. "Relationship Damage Bristle Brush with Level Hygiene Teeth grade V State Elementary School V Ciawi Tasikmalaya". Journal ARSA (Actual Research Science Academic). 2 (2), 35 - 40, 2017.

[11] Pintauli, S. Analysis of Behavior Relationship of Dental and Oral Health Care on Dental and Oral Health Status of Elementary and Junior High School Students in Medan. Jurnal Pendidikan dan Kebudayaan. 16 (4), 376 - 390 , 2010.

[12] Notoatmodjo, S. Public Health Sciences. Rineka Cipta. Jakarta, 108-12, 2003.

[13] Notoatmodjo, S. Public Health Sciences and Art. Rineka Cipta. Jakarta, 32-7, 2007.

[14] Susilana, R., Riyana, C. Instructional Media. Wacana Prima. Bandung, 8, 2009.

[15] Mudlofir, A., Rusydiyah, E.F. Innovative Learning Design. Raja Grafindo Persada. Jakarta. 115-7, 2016.

[16] Puspitaningtiyas, R., Leman, M. A., Juliatri. "Comparison of the Effectiveness of Dental Health Education Methods of Lectures and Methods of Simulation Game on Improving Child and Dental Health Knowledge". Jurnal e-Gigi (eG). 5 (1), 68 - 73, 2017.

[17] Sumantri, D., Yuniar, L., Mustika A. "Effect of Dental and Oral Knowledge Level Changes on 7-8 Years of Aged Students at 2 Primary Schools of Sub-district of Mandiangin Selayan Bukittinggi City through Educational Game of Dentistry". Andalas Jurnal. 1 (1), 2013.

[18] Zainal. Media Models and Contextual Learning Strategies (Inovatif). Yrama Widya. Bandung, 13, 2013.

[19] Hidayanti, Lilik. "Relationship of Family Characteristics and Habits of Kosogenic Food Consumption with Severity of Dental Caries Primary School Children”. Thesis. Universitas Diponegoro, Semarang, 2005.

[20] Putri. "The Effect of Dental Education by Using the Jaw Model Compared with the Mentoring Method on the Dental and Mouth Hygiene Levels of Blind Students Special School-A Bandung". Periodical Medicine Magazine. 46 (3), 134-142, 2014.

[21] Suiroka, I. P., Supariasa, I. D. N. Media Health Education. Graha Ilmu. Yogyakarta, 5-7, 2012.

[22] Kantohe, Z. R., Vonny, N. S. W., Paulina, N. G. "Comparative Effectiveness of Dental Health Education Using Video Media and Flip Chart on Improving Child and Dental Health Knowledge”. Jurnal e-Gigi (eG). 4 (2) 96-101, 2016.

[23] Bagaray, F. E. K., Vonny, N. S. W., Christy N. M. "DHE Effectiveness Difference with Media Booklet and Media Flip Chart on Improving Dental and Oral Health Knowledge of Students of Elementary School Students 126 Manado". Jurnal e-Gigi (eG). 4 (2), 76-82, 2016.

[24] Tandilangi, M., Christy, M., Vonny N. S.W. Effectiveness of Dental Health Education with Cartoon Animation Media Against Change of Dental and Oral Health Behavior of Seventh Elementary School Students Advent 02 Sario Manado, Jurnal e-Gigi (eG). 4 (2), 106 - 110, 2016.

[25] Papilaya, E. A., Kustina, Z., Juiatri. "Comparison of Influence of Health Promotion Using Audio Media with Audio Visual Media to Dental and Oral Health Behavior of Elementary School Students". Jurnal e-Gigi (eG). 4 (2), 282-286, 2016.

[26] Nurhidayat, O., Eram, T. P, Bambang W. "Comparison of Power Point Media with Flip Chart in Improving Dental and Oral Health Knowledge”. Unnes Journal of Public Health. 1(1), 31-35, 2012.

[27] Debnath, T. Ashok'S Public Health and Preventive Dentistry, 2nd ed., AITBS Publishers \& Distributors (Regd.). India, 8-30, 2002.

[28] Indonesia Ministry of Health. Guidance of School Dental Health Effort. Jakarta, 2004. 